\title{
Effect of Post-ERCP Pancreatitis on Perioperative Factors of Pancreaticoduodenectomy
}

\author{
Teijiro Hirashita ${ }^{*}$, Toshifumi Matsumoto' ${ }^{1}$ Koichi Izumi ${ }^{1}$, Masahiko Ikebe${ }^{1}$, \\ Tokujiro Yano', Yoichi Mutoํㅜ, Susumu Matsuo² \\ ${ }^{1}$ Department of Surgery, National Hospital Organization Beppu Medical Center, Beppu, Japan \\ ${ }^{2}$ Department of Gastroenterology, National Hospital Organization Beppu Medical Center, Beppu, Japan \\ Email: teij03@oita-u.ac.jp
}

Received 15 January 2015; accepted 5 February 2015; published 9 February 2015

Copyright (C) 2015 by authors and Scientific Research Publishing Inc.

This work is licensed under the Creative Commons Attribution International License (CC BY). http://creativecommons.org/licenses/by/4.0/

\section{(c) (i) Open Access}

\begin{abstract}
Background: Endoscopic retrograde cholangiopancreatography (ERCP) is commonly performed for biliary drainage and examination of the biliary and pancreatic duct before pancreaticoduodenectomy (PD). The influence of preoperative post-ERCP pancreatitis on PD is unknown. The aim of this study was to evaluate the relation between post-ERCP pancreatitis before PD and surgical outcomes of PD. Methods: We examined 38 patients who underwent PD. The relations between post-ERCP pancreatitis before PD and perioperative factors of PD such as patient characteristics, operative findings, and postoperative course were evaluated with univariate and multivariate analyses. Results: Post-ERCP pancreatitis was observed in 12 (37.5\%) of the 38 patients. Univariate analyses showed operative procedure $(P=0.034)$, operation time $(P=0.004), \operatorname{blood} \operatorname{loss}(P=$ 0.031), C-reactive protein $(P=0.043)$, and delayed gastric emptying $(P=0.035)$ to be significantly associated with post-ERCP pancreatitis. Multivariate analyses showed operation time (OR, 1.017; 95\%CI, 1.000 - 1.034; $P=0.049)$ and delayed gastric emptying (OR, 18.72; 95\%CI, 1.139 - 307.6; $P=0.040)$ to be significantly associated with post-ERCP pancreatitis. Conclusions: Post-ERCP pancreatitis was associated with prolonged operation time and delayed gastric emptying in patients undergoing PD.
\end{abstract}

\section{Keywords}

Endoscopic Retrograde Cholangiopancreatography, Post-ERCP Pancreatitis, Pancreaticoduodenectomy

\footnotetext{
${ }^{*}$ Corresponding author.
}

How to cite this paper: Hirashita, T., Matsumoto, T., Izumi, K., Ikebe, M., Yano, T., Muto, Y. and Matsuo, S. (2015) Effect of Post-ERCP Pancreatitis on Perioperative Factors of Pancreaticoduodenectomy. Surgical Science, 6, 35-41. 


\section{Introduction}

Endoscopic retrograde cholangiopancreatography (ERCP) is commonly performed for patients with periampullary cancer or cancer of the pancreas head to examine the biliary and pancreatic ducts. However, ERCP is associated with a relatively high complication rate. The reported incidence of complications ranges from $5 \%$ to $40 \%$, depending on the complexity of the procedure, the underlying diagnosis, and patient co-morbidities [1]-[3]. Pancreatitis is seen as the most frequent complication of ERCP, followed by cholangitis, duodenal hemorrhage, and duodenal perforation [1]-[3]. Post-ERCP pancreatitis is a feared complication that is associated with substantial morbidity and occasional mortality [4] [5].

Pancreaticoduodenectomy (PD) is also performed for patients with periampullary and pancreas head cancer because of the possibility of curative treatment. PD is one of the most complex abdominal surgeries, requiring high-quality techniques and perioperative management. Postoperative mortality after PD has decreased to below 5\% in the past 10 - 15 years [6]-[8]. However, mortality is still high, and overall morbidity, including that from pancreatic fistula, delayed gastric emptying, intra-abdominal bleeding, and intra-abdominal abscess, has remained high, ranging from 30\% - 60\% [9]-[11]. In particular, pancreatic fistula still occurs in 5\% to $40 \%$ of patients [11]-[13], and delayed gastric emptying occurs in 22\% to 52\% of patients undergoing PD [14] [15] despite refinements in surgical techniques and methods of perioperative management.

It is possible that post-ERCP pancreatitis can cause fibrosis and adhesions of the pancreas and surrounding tissue. These complications might increase both the surgical difficulty of subsequent PD and the risk of complications. However, scarce data are available on the influence of previous post-ERCP pancreatitis on PD. The aim of this study was to evaluate the relation between post-ERCP pancreatitis before PD and surgical outcomes of PD.

\section{Patients and Methods}

\subsection{Patients}

Between January 2009 and December 2012, 38 consecutive Japanese patients underwent PD, including pylorus-preserving PD (PPPD) and subtotal stomach-preserving PD (SSPPD), at the Department of Surgery, National Hospital Organization Beppu Medical Center, Oita, Japan. Patient characteristics, operative findings, and postoperative course were examined retrospectively. We followed the ethical principles stated in the guidelines of the World Medical Association's Declaration of Helsinki in this study.

\subsection{Assessment of Post-ERCP Pancreatitis}

According to the criteria of Cotton et al., post-ERCP pancreatitis was diagnosed by the presence of a serum amylase level of over three times the upper limit of normal (>375IU/L) at approximately $18 \mathrm{~h}$ (the next morning) after the surgical procedure [16].

\subsection{Definition of Operative Complications}

According to the definition by the ISGPF [17], pancreatic fistula was classified as one of four categories: no fistula, biochemical evidence of fistula as defined by surgical drain amylase level greater than three times the serum level without clinical consequence (grade A), biochemical evidence of fistula requiring clinical intervention such as percutaneous drainage or total parental nutrition (grade B), and biochemical evidence of fistula with severe clinical sequelae necessitating intensive care unit admission or re-operation (grade C). Gastric emptying was considered delayed when postoperative gastric suction was required for more than 10 days or when there was an inability to tolerate a solid diet on or before the 14th postoperative day [14] [18]. Diagnoses were histopathologically assessed after surgery.

\subsection{Univariate and Multivariate Analyses}

The patients were divided into two groups: post-ERCP pancreatitis $(+)$ and $(-)$. Patients who did not undergo ERCP were included in the post-ERCP pancreatitis (-) group. Univariate analysis was performed to compare the perioperative characteristics between the post-ERCP pancreatitis $(+)$ group and $(-)$ group. We included the following 13 potentially important factors in the analyses, considering their clinical significance: 1 ) operative 
procedure (PPPD vs others), 2) reconstruction of portal vein 3) operation time, 4) blood loss, 5) blood transfusion (yes vs no), 6) diagnosis (pancreas cancer vs others), 7) white blood cell count on postoperative day 1, 8) serum amylase level on postoperative day 1, 9) C-reactive protein (CRP) level on postoperative day 3, 10) clinically significant (grade B and C) pancreatic fistula, 11) duration of intraabdominal drainage after surgery, 12) delayed gastric emptying (yes or no), and 13) hospital stay after surgery.

Similarly, multivariate analysis was performed to identify the most valuable clinical characteristics associated with post-ERCP pancreatitis from among those selected by the univariate analysis.

\subsection{Statistical Analysis}

All data are expressed as means \pm SD. Results of the univariate and multivariate logistic regression analyses are expressed as adjusted odds ratio (OR) with 95\% confidence interval (CI). A value of $P<0.05$ was considered to be statistically significant. All statistical analyses were performed with Dr. SPSS II software version $11.01 \mathrm{~J}$ (SPSS Japan Inc., Tokyo, Japan).

\section{Results}

\subsection{Patient Characteristics and Perioperative Factors}

No operative mortality occurred in the 38 patients. Patient characteristics and perioperative factors are shown in Table 1. The patients comprised 25 men and 13 women (male-to-female ratio: 1.9:1) with a mean age of $71.5 \pm$ 9.0 years. The surgical procedures used were PPPD in 24 patients, SSPPD in 7, and PD in 7. Mean operation time was $478 \pm 98 \mathrm{~min}$, and mean blood loss was $1424 \pm 1630 \mathrm{ml}$. Of the 38 patients, 22 (59.5\%) required blood

\begin{tabular}{|c|c|}
\hline Age & $71.5 \pm 9.0$ \\
\hline Sex (male/female) & $24 / 14$ \\
\hline $\operatorname{BMI}\left(\mathrm{kg} / \mathrm{m}^{2}\right)$ & $20.9 \pm 3.3$ \\
\hline Preoperative serum bilirubin (mg/dl) & $1.1 \pm 0.9$ \\
\hline \multicolumn{2}{|l|}{ Operative procedure } \\
\hline PPPD & 24 \\
\hline SSPPD & 7 \\
\hline PD & 7 \\
\hline Reconstruction of portal vein & 7 \\
\hline Operation time (min) & $478 \pm 98$ \\
\hline Blood loss (ml) & $1424 \pm 1630$ \\
\hline Transfusion & 22 \\
\hline \multicolumn{2}{|l|}{ Diagnosis } \\
\hline Pancreas cancer & 25 \\
\hline Bile duct cancer & 7 \\
\hline Cancer of ampulla of Vater & 3 \\
\hline Others & 3 \\
\hline \multicolumn{2}{|l|}{ Postoperative Laboratory tests } \\
\hline White blood cell $(/ \mu \mathrm{l})$ & $8971 \pm 2831$ \\
\hline Serum amylase (IU/L) & $160 \pm 185$ \\
\hline C-reactive protein (mg/dl) & $13.9 \pm 5.5$ \\
\hline Removal of drainage tube (days) & $17.2 \pm 9.3$ \\
\hline Pancreatic fistula & 8 \\
\hline Delayed gastric emptying & 8 \\
\hline Hospital stay (days) & $39.2 \pm 11.7$ \\
\hline
\end{tabular}

BMI: body mass index; PPPD: pylorus-preserving pancreaticoduodenectomy; SSPPD: subtotal stomach-preserving pancreaticoduodenectomy; PD: pancreaticoduodenectomy. Data are expressed as mean \pm SD. 
transfusion. The diseases warranting PD included pancreas cancer in 25 patients, bile duct cancer in 7, cancer of the ampulla of Vater in 3, and others in 3 patients.

\subsection{Characteristics of the ERCP Procedure}

Characteristics of the ERCP procedure are presented in Table 2. ERCP was performed for 32 patients, and 23 patients underwent endoscopic retrograde biliary drainage. The average serum bilirubin before ERCP was $4.3 \pm$ $4.1 \mathrm{mg} / \mathrm{dl}$. The average serum amylase level at approximately $18 \mathrm{~h}$ after ERCP was $461 \pm 662 \mathrm{IU} / \mathrm{L}$, and postERCP pancreatitis was observed in 12 (37.5\%) of the 32 patients. Duration between ERCP and the PD operation was $28 \pm 15$ days.

\subsection{Outcomes of Univariate Analysis}

The results of univariate analysis of factors related to post-ERCP pancreatitis are shown in Table 3. Operative procedure, operation time, blood loss, C-reactive protein, and delayed gastric emptying were found to be significantly associated with post-ERCP pancreatitis.

\subsection{Outcomes of Multivariate Analysis}

Results of multivariate analysis of factors related to post-ERCP pancreatitis are shown in Table 4. Multivariate analysis was performed using the 5 factors selected by univariate analysis. Operation time (OR, 1.017; 95\%CI, $1.000-1.034 ; P=0.049$ ) and delayed gastric emptying (OR, 18.72; 95\%CI, $1.139-307.6 ; P=0.040$ ) were found to be significantly associated with post-ERCP pancreatitis.

Table 2. Results of ERCP $(\mathrm{n}=32)$.

\begin{tabular}{lc}
\hline ERBD & 23 \\
Serum bilirubin (mg/dl) before ERCP & $4.3 \pm 4.1$ \\
Serum amylase (IU/L) after ERCP & $461 \pm 662$ \\
Post-ERCP pancreatitis & 12 \\
Duration between ERCP and operation (days) & $28 \pm 15$ \\
\hline
\end{tabular}

ERCP: endoscopic retrograde cholangiopancreatography; ERBD: endoscopic retrograde biliary drainage.

Table 3. Univariate analysis regarding post-ERCP pancreatitis.

\begin{tabular}{|c|c|c|c|}
\hline & post-ERCP pancreatitis $(-) n=26$ & post-ERCP pancreatitis $(+) n=12$ & $P$ value \\
\hline Operative procedure (PPPD/others) & $20 / 6$ & $4 / 8$ & 0.034 \\
\hline Reconstruction of portal vein & 3 & 4 & 0.113 \\
\hline Operation time (min) & $446 \pm 58$ & $542 \pm 133$ & 0.004 \\
\hline Blood loss (ml) & $1037 \pm 779$ & $2235 \pm 2501$ & 0.031 \\
\hline Blood transfusion & 14 & 8 & 0.470 \\
\hline Diagnosis (pancreas cancer/others) & $15 / 11$ & $9 / 3$ & 0.317 \\
\hline \multicolumn{4}{|l|}{ Postoperative Laboratory tests } \\
\hline White blood cell $(/ \mu \mathrm{l})$ & $8797 \pm 2769$ & $9348 \pm 3050$ & 0.583 \\
\hline Serum amylase (IU/L) & $137 \pm 140$ & $210 \pm 259$ & 0.266 \\
\hline C-reactive protein (mg/dl) & $12.6 \pm 5.5$ & $16.5 \pm 4.9$ & 0.043 \\
\hline Removal of drainage tube (days) & $16 \pm 7$ & $19 \pm 13$ & 0.333 \\
\hline Pancreatic fistula & 5 & 3 & 0.738 \\
\hline Delayed gastric emptying & 3 & 5 & 0.035 \\
\hline Hospital stay (days) & $39 \pm 12$ & $39 \pm 12$ & 0.989 \\
\hline
\end{tabular}

ERCP: endoscopic retrograde cholangiopancreatography; PPPD: pylorus preserving pancreaticoduodenectomy; SSPPD: subtotal stomach preserving pancreaticoduodenectomy; PD: pancreaticoduodenectomy. 
Table 4. Multivariate logistic regression analysis regarding post-ERCP pancreatitis.

\begin{tabular}{lccc}
\hline & OR & 95\%CI & $P$ value \\
\hline Operative procedure & 5.388 & $0.660-44.01$ & 0.116 \\
Operation time & 1.017 & $1.000-1.034$ & 0.049 \\
Blood loss & 1.000 & $0.999-1.001$ & 0.958 \\
Postoperative C-reactive protein & 1.049 & $0.869-1.265$ & 0.619 \\
Delayed gastric emptying & 18.720 & $1.139-307.6$ & 0.040 \\
\hline
\end{tabular}

ERCP: endoscopic retrograde cholangiopancreatography; OR: odds ratio; CI: confidence interval.

\section{Discussion}

The present study examined the relation between post-ERCP pancreatitis before PD and 13demographic, clinicopathological, and surgical factors of PD. Multivariate analyses revealed that operative time and delayed gastric emptying were significantly associated with post-ERCP pancreatitis. The present study suggests that the occurrence of post-ERCP pancreatitis may lead to prolonged operation time and postoperative delayed gastric emptying.

ERCP is often performed for the diagnosis and treatment of periampullary cancer, such as cancer of the pancreas head, bile duct, and ampulla of Vater. Whereas the overall incidence of post-ERCP pancreatitis ranges from $1 \%$ to $6 \%$, the incidence of post-ERCP pancreatitis may exceed $30 \%$ in patients considered to be high risk [3] [5] [19]. Younger patients, difficult cannulation, a cut or dilated papilla, and $>1$ injection of contrast into the pancreatic duct are associated with post-ERCP pancreatitis [2]. In the present study, post-ERCP pancreatitis was associated with operation time and delayed gastric emptying. Therefore, appropriate technical prophylaxis during ERCP, such as avoiding cutting of the papilla and plural injections of contrast into the pancreatic duct, should be considered in preoperative patients with periampullary cancer.

In the present study, post-ERCP pancreatitis led to prolonged operation time. Post-ERCP pancreatitis may be associated with adhesions around the pancreatic head. In patients undergoing PD, we sometimes encounter difficulty when dissecting around the pancreatic head due to adhesions, although there is no cancerous invasion to surrounding structures such as the portal vein, supramesenteric vein, and mesenterium of the transverse colon. When there is an adhesion between the pancreas and the portal vein, the surgeon must operate carefully. As a result, operation time may be prolonged in such cases.

Delayed gastric emptying is one of the most common complications after PD [20] [21]. Although an imbalance in gastrointestinal peptides due to resection of the duodenum is reported as one reason for this, not all patients undergoing PD suffer this complication. The cause has not been well understood. It was initially reported that the incidence of delayed gastric emptying was higher in patients undergoing PPPD than in those undergoing standard PD with antrectomy [18]; however, this theory was denied in the later literature [21]. Some evidence has been reported previously on the association between delayed gastric emptying and postoperative complications, such as pancreatic fistula, postoperative pancreatitis, and overall complications [15] [22]. In the present study, post-ERCP pancreatitis was associated with delayed gastric emptying. Inflammation around the pancreas head and prolonged operation time caused by post-ERCP pancreatitis may lead to delayed gastric emptying.

Preoperative biliary drainage was performed routinely in the patients with obstructive jaundice caused by periampullary cancer in this series. In many centers, preoperative biliary drainage has been incorporated into the surgical treatment of the periampullary cancer. Presently, the necessity for preoperative biliary drainage is controversial. In several studies, preoperative biliary drainage reduced morbidity and mortality after surgery for periampullary cancer [23] [24]. However, recent studies showed that the overall complication rate in patients undergoing preoperative biliary drainage was higher than that in patients who proceeded directly to surgery and that the procedure increased the rate of complications [25] [26]. This difference was partially explained by complications associated with the preoperative biliary drainage procedure itself. ERCP is useful for diagnosis and treatment of patients with jaundice due to periampullary cancer. However, if preoperative ERCP for biliary drainage is not needed, then ERCP may also not be needed for patients who can be diagnosed by non-invasive methods such as computed tomography and magnetic resonance cholangiopancreatography. 


\section{Conclusion}

In conclusion, the present retrospective study suggested that the occurrence of post-ERCP pancreatitis may lead to prolonged operation time and delayed gastric emptying in patients undergoing PD.

\section{Conflict of Interest}

All authors declare no conflicts of interest.

\section{Financial Support}

No financial support was received for this study.

\section{References}

[1] Vandervoort, J., Soetikno, R.M., Tham, T.C., Wong, R.C., Ferrari Jr., A.P., Montes, H., Roston, A.D., Slivka, A., Lichtenstein, D.R., Ruymann, F.W., Van Dam, J., Hughes, M. and Carr-Locke, D.L. (2002) Risk Factors for Complications after Performance of ERCP. Gastrointestinal Endoscopy, 6, 652-656. http://dx.doi.org/10.1016/S0016-5107(02)70112-0

[2] Silviera, M.L., Seamon, M.J., Porshinsky, B., Prosciak, M.P., Doraiswamy, V.A., Wang, C.F., Lorenzo, M., Truitt, M., Biboa, J., Jarvis, A.M., Narula, V.K., Steinberg, S.M. and Stawicki, S.P. (2009) Complications Related to Endoscopic Retrograde Cholangiopancreatography: A Comprehensive Clinical Review. Journal of Gastrointestinal and Liver Diseases, 18, 73-82.

[3] Jeurnink, S.M., Siersema, P.D., Steyerberg, E.W., Dees, J., Poley, J.W., Haringsma, J. and Kuipers, E.J. (2011) Predictors of Complications after Endoscopic Retrograde Cholangiopancreatography: A Prognostic Model for Early Discharge. Surgical Endoscopy, 25, 2892-2900. http://dx.doi.org/10.1007/s00464-011-1638-9

[4] Cheng, C.L., Sherman, S., Watkins, J.L., Barnett, J., Freeman, M., Geenen, J., Ryan, M., Parker, H., Frakes, J.T., Fogel, E.L., Silverman, W.B., Dua, K.S., Aliperti, G., Yakshe, P., Uzer, M., Jones, W., Goff, J., Lazzell-Pannell, L., Rashdan, A., Temkit, M. and Lehman, G.A. (2006) Risk Factors for Post-ERCP Pancreatitis: A Prospective Multicenter Study. American Journal of Gastroenterology, 101, 139-147. http://dx.doi.org/10.1111/j.1572-0241.2006.00380.x

[5] Freeman, M.L. (2002) Adverse Outcomes of ERCP. Gastrointestinal Endoscopy, 56, S273-S282. http://dx.doi.org/10.1016/S0016-5107(02)70025-4

[6] Trede, M. and Schwall, G. (1988) The Complications of Pancreatectomy. Annals of Surgery, 207, 39-47. http://dx.doi.org/10.1097/00000658-198801000-00009

[7] Räty, S., Sand, J., Lantto, E. and Nordback, I. (2006) Postoperative Acute Pancreatitis as a Major Determinant of Postoperative Delayed Gastric Emptying after Pancreaticoduodenectomy. Journal of Gastrointestinal Surgery, 10, 1131-1139. http://dx.doi.org/10.1016/j.gassur.2006.05.012

[8] Balzano, G., Zerbi, A., Capretti, G., Rocchetti, S., Capitanio, V. and Di Carlo, V. (2008) Effect of Hospital Volume on Outcome of Pancreaticoduodenectomy in Italy. British Journal of Surgery, 95, 357-362. http://dx.doi.org/10.1002/bjs.5982

[9] Seiler, C.A., Wagner, M., Bachmann, T., Redaelli, C.A., Schmied, B., Uhl, W., Friess, H. and Büchler, M.W. (2005) Randomized Clinical Trial of Pylorus-Preserving Duodenopancreatectomy versus Classical Whipple Resection-Long Term Results. British Journal of Surgery, 92, 547-556. http://dx.doi.org/10.1002/bjs.4881

[10] Yeo, C.J., Cameron, J.L., Lillemoe, K.D., Sohn, T.A., Campbell, K.A., Sauter, P.K., Coleman, J., Abrams, R.A. and Hruban, R.H. (2002) Pancreaticoduodenectomy with or without Distal Gastrectomy and Extended Retroperitoneal Lymphadenectomy for Periampullary Adenocarcinoma, Part 2: Randomized Controlled Trial Evaluating Survival, Morbidity, and Mortality. Annals of Surgery, 236, 355-366. http://dx.doi.org/10.1097/00000658-200209000-00012

[11] Braga, M., Capretti, G., Pecorelli, N., Balzano, G., Doglioni, C., Ariotti, R. and Di Carlo, V. (2011) A Prognostic Score to Predict Major Complications after Pancreaticoduodenectomy. Annals of Surgery, 254, 702-708. http://dx.doi.org/10.1097/SLA.0b013e31823598fb

[12] Tani, M., Kawai, M., Hirono, S., Ina, S., Miyazawa, M., Shimizu, A. and Yamaue, H. (2010) A Prospective Randomized Controlled Trial of Internal versus External Drainage with Pancreaticojejunostomy for Pancreaticoduodenectomy. American Journal of Surgery, 199, 759-764. http://dx.doi.org/10.1016/j.amjsurg.2009.04.017

[13] Roder, J.D., Stein, H.J., Bottcher, K.A., Busch, R., Heidecke, C.D. and Siewert, J.R. (1999) Stented versus Nonstented Pancreaticojejunostomy after Pancreatoduodenectomy: A Prospective Study. Annals of Surgery, 229, 41-48. http://dx.doi.org/10.1097/00000658-199901000-00005 
[14] Tani, M., Terasawa, H., Kawai, M., Ina, S., Hirono, S., Uchiyama, K. and Yamaue, H. (2006) Improvement of Delayed Gastric Emptying in Pylorus-Preserving Pancreaticoduodenectomy: Results of a Prospective, Randomized, Controlled Trial. Annals of Surgery, 43, 316-320. http://dx.doi.org/10.1097/01.sla.0000201479.84934.ca

[15] Murakami, Y., Uemura, K., Sudo, T., Hayashidani, Y., Hashimoto, Y., Nakagawa, N., Ohge, H. and Sueda, T. (2008) An Antecolic Roux-en Y Type Reconstruction Decreased Delayed Gastric Emptying after Pylorus-Preserving Pancreatoduodenectomy. Journal of Gastrointestinal Surgery, 12, 1081-1086. http://dx.doi.org/10.1007/s11605-008-0483-1

[16] Cotton, P.B., Lehman, G., Vennes, J., Geenen, J.E., Russell, R.C., Meyers, W.C., Liguory, C. and Nickl, N. (1991) Endoscopic Sphincterotomy Complications and Their Management: An Attempt at Consensus. Gastrointestinal Endoscopy, 37, 383-393. http://dx.doi.org/10.1016/S0016-5107(91)70740-2

[17] Bassi, C., Dervenis, C., Butturini, G., Fingerhut, A., Yeo, C., Izbicki, J., Neoptolemos, J., Sarr, M., Traverso, W. and Buchler, M. (2005) Postoperative Pancreatic Fistula: An International Study Group (ISGPF) Definition. Surgery, 138, 8-13. http://dx.doi.org/10.1016/j.surg.2005.05.001

[18] van Berge Henegouwen, M.I., van Gulik, T.M., Allema, J.H., Rauws, E.A., Obertop, H. and Gouma, D.J. (1997) Delayed Gastric Emptying after Standard Pancreaticoduodenectomy versus Pylorus-Preserving Pancreaticoduodenectomy: An Analysis of 200 Consecutive Patients. Journal of the American College of Surgeons, 185, 373-379. http://dx.doi.org/10.1016/S1072-7515(97)00078-1

[19] Masci, E., Toti, G., Mariani, A., Curioni, S., Lomazzi, A., Dinelli, M., Minoli, G., Crosta, C., Comin, U., Fertitta, A., Prada, A., Passoni, G.R. and Testoni, P.A. (2001) Complications of Diagnostic and Therapeutic ERCP: A Prospective Multicenter Study. American Journal of Gastroenterology, 96, 417-423. http://dx.doi.org/10.1111/j.1572-0241.2001.03594.x

[20] Miedema, B.W., Sarr, M.G., van Heerden, J.A., Nagorney, D.M., Mc Ilrath, D.C. and Ilstrup, D. (1992) Complications Following Pancreaticoduodenectomy: Current Management. Archives of Surgery, 127, 945-949. http://dx.doi.org/10.1001/archsurg.1992.01420080079012

[21] Hackert, T., Hinz, U., Hartwig, W., Strobel, O., Fritz, S., Schneider, L., Werner, J. and Büchler, M.W. (2013) Pylorus Resection in Partial Pancreaticoduodenectomy: Impact on Delayed Gastric Emptying. American Journal of Surgery, 206, 296-299. http://dx.doi.org/10.1016/j.amjsurg.2012.10.042

[22] Braasch, J.W., Deziel, D.J., Rossi, R.L., Watkins Jr., E. and Winter, P.F. (1986) Pyloric and Gastric Preserving Pancreatic Resection: Experience with 87 Patients. Annals of Surgery, 204, 411-418. http://dx.doi.org/10.1097/00000658-198610000-00009

[23] van der Gaag, N.A., Kloek, J.J., de Castro, S.M., Busch, O.R., van Gulik, T.M. and Gouma, D.J. (2009) Preoperative Biliary Drainage in Patients with Obstructive Jaundice: History and Current Status. Journal of Gastrointestinal Surgery, 13, 814-820. http://dx.doi.org/10.1007/s11605-008-0618-4

[24] Kimmings, A.N., van Deventer, S.J., Obertop, H., Rauws, E.A., Huibregtse, K. and Gouma, D.J. (2000) Endotoxin, Cytokines, and Endotoxin Binding Proteins in Obstructive Jaundice and after Preoperative Biliary Drainage. Gut, 46, 725-731. http://dx.doi.org/10.1136/gut.46.5.725

[25] Sewnath, M.E., Karsten, T.M., Prins, M.H., Rauws, E.J., Obertop, H. and Gouma, D.J. (2002) A Meta-Analysis on the Efficacy of Preoperative Biliary Drainage for Tumors Causing Obstructive Jaundice. Annals of Surgery, 236, 17-27. http://dx.doi.org/10.1097/00000658-200207000-00005

[26] van der Gaag, N.A., Rauws, E.A., van Eijck, C.H., Bruno, M.J., van der Harst, E., Kubben, F.J., Gerritsen, J.J., Greve, J.W., Gerhards, M.F., de Hingh, I.H., Klinkenbijl, J.H., Nio, C.Y., de Castro, S.M., Busch, O.R., van Gulik, T.M., Bossuyt, P.M. and Gouma, D.J. (2010) Preoperative Biliary Drainage for Cancer of the Head of the Pancreas. New England Journal of Medicine, 362, 129-137. http://dx.doi.org/10.1056/NEJMoa0903230 
Scientific Research Publishing (SCIRP) is one of the largest Open Access journal publishers. It is currently publishing more than 200 open access, online, peer-reviewed journals covering a wide range of academic disciplines. SCIRP serves the worldwide academic communities and contributes to the progress and application of science with its publication.

Other selected journals from SCIRP are listed as below. Submit your manuscript to us via either submit@scirp.org or Online Submission Portal.
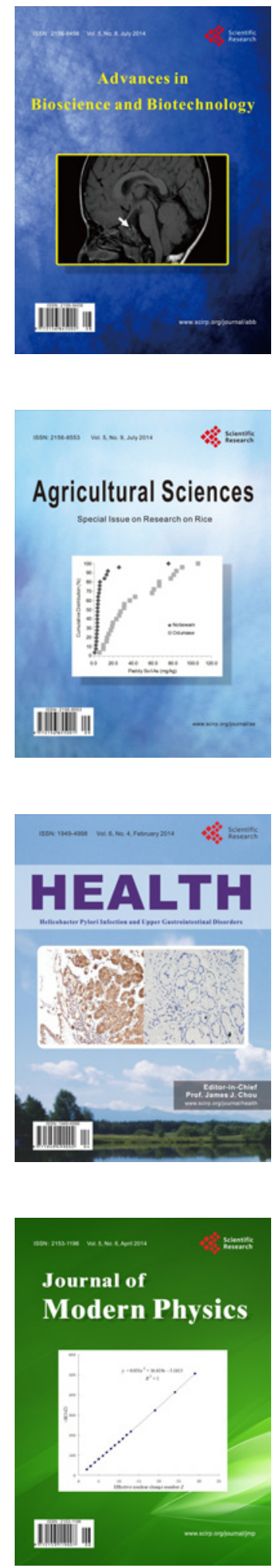
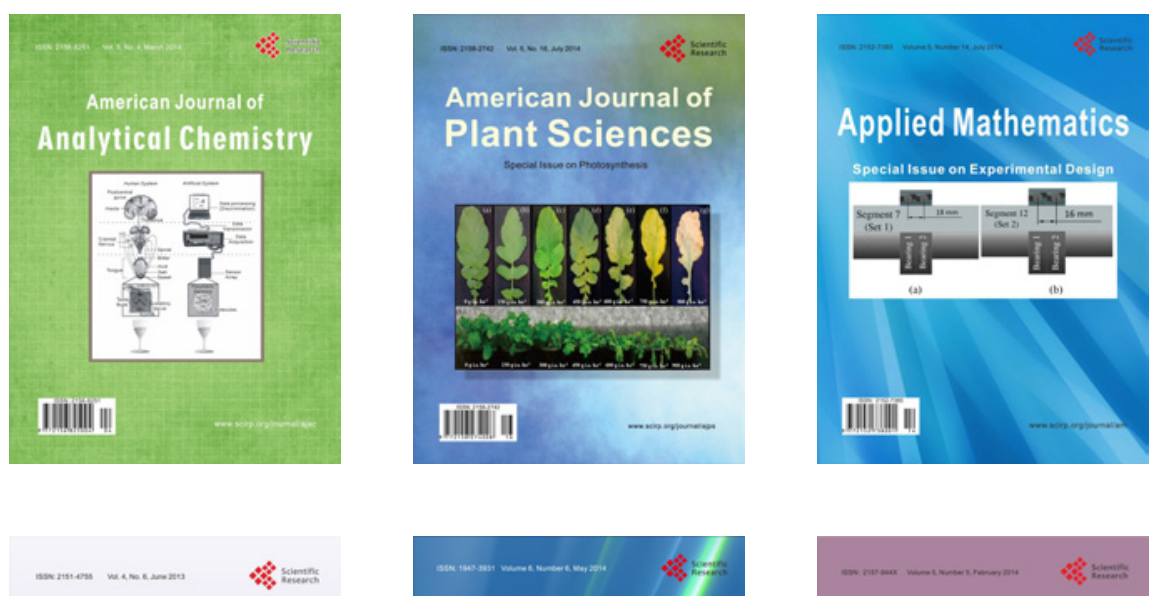

Creative Education
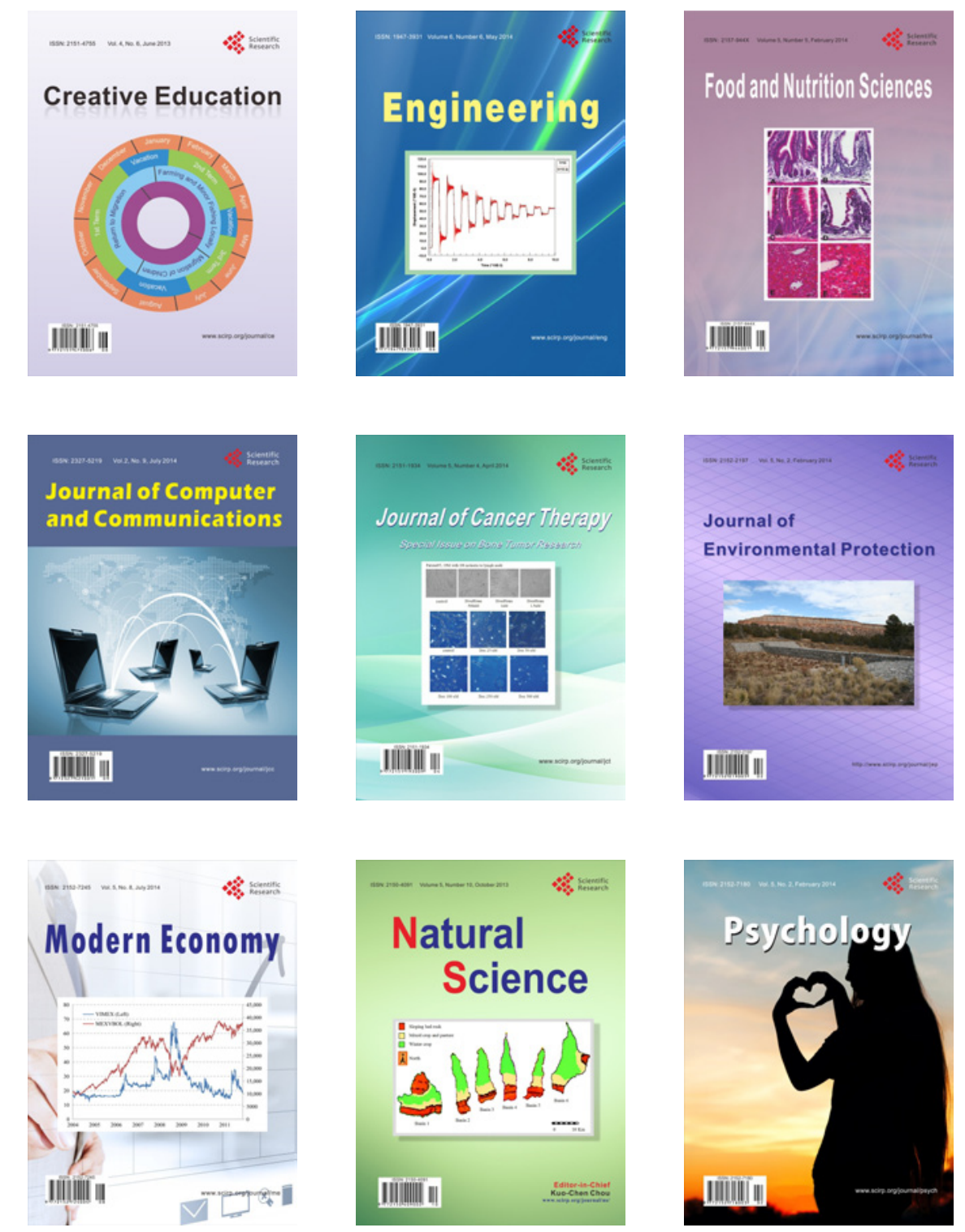